\begin{tabular}{r|l|l|l}
$\begin{array}{c}\text { Case Reports in } \\
\text { Gastroenterology }\end{array}$ & $\begin{array}{l}\text { Case Rep Gastroenterol 2011;5:136-138 } \\
\text { DOl: 10.1159/000326939 }\end{array}$ & $\begin{array}{l}\text { Published online: } \\
\text { April 6, 2011 }\end{array}$ & $\begin{array}{l}\text { O 2011 S. Karger AG, Basel } \\
\text { ISSN 1662-0631 } \\
\text { www.karger.com/crg }\end{array}$ \\
\hline
\end{tabular}

This is an Open Access article licensed under the terms of the Creative Commons AttributionNonCommercial-NoDerivs 3.0 License (www.karger.com/OA-license), applicable to the online version of the article only. Distribution for non-commercial purposes only.

\title{
Gastric Ulcer Revealed by Computed Tomography in a Patient with Tongue Cancer after Percutaneous Gastrostomy
}

\author{
Masafumi Mizuide Satoru Kakizaki Sachiko Yoshida \\ Masatomo Mori
}

Department of Medicine and Molecular Science, Gunma University Graduate School of Medicine, Maebashi, Japan

\section{Key Words}

Gastric ulcer · Computed tomography

\begin{abstract}
With the advances in computed tomography (CT) imaging, CT can result in precise imaging, even of the gastrointestinal tract. However, the diagnostic quality of endoscopy is superior to $\mathrm{CT}$ because of precise mucosal observations or biopsy procedure. In the present case, CT was useful in the diagnosis of a gastric ulcer because endoscopy was deemed too difficult to perform due to tongue cancer occupying the oral space. Three-dimensional reconstruction of the $\mathrm{CT}$ images revealed an ulcerous lesion at the upper posterior wall of the stomach. CT may therefore be helpful for the diagnosis of gastric lesions when usual endoscopy is difficult to perform, as observed in the present patient.
\end{abstract}

\section{Case Report}

A 77-year-old female patient presented to the Gastroenterology Department with abdominal discomfort. She was suffering from tongue cancer and swallowing disturbances. Because of the swallowing disturbance and tumor growth, the patient received nutrition via percutaneous gastrostomy. Physical examination was unremarkable aside from slight epigastric tenderness. There were no findings showing muscular defenses. There were no symptoms of gastrointestinal bleeding, such as tarry stool. The percutaneous gastrostomy tube was observed to be in the epigastrium. Investigations demonstrated a hemoglobin level of $9.8 \mathrm{~g} / \mathrm{dl}$, a white blood cell count of $4,800 / \mu \mathrm{l}$, a platelet count of $35.0 \times 10^{4} / \mu \mathrm{l}$ and a C-reactive protein level of $0.5 \mathrm{mg} / \mathrm{dl}$. The tongue cancer occupied the oral space, but no complete obstruction was observed.

We chose abdominal computed tomography (CT) before endoscopic examination for evaluating the reason for abdominal discomfort and the status of the percutaneous gastrostomy tube. There were no signs of tube deviation, free air or liquid retention around the site of tube insertion. However, CT revealed a mucosal defect and a round deep cavity in the upper posterior wall of the stomach (arrow; 


\begin{tabular}{r|l|l|l}
$\begin{array}{r}\text { Case Reports in } \\
\text { Gastruenterology }\end{array}$ & $\begin{array}{l}\text { Case Rep Gastroenterol 2011;5:136-138 } \\
\text { DOI: 10.1159/000326939 }\end{array}$ & $\begin{array}{l}\text { Published online: } \\
\text { April 6, 2011 }\end{array}$ & $\begin{array}{l}\text { O 2011 S. Karger AG, Basel } \\
\text { ISSN 1662-0631 } \\
\text { www.karger.com/crg }\end{array}$ \\
\hline
\end{tabular}

fig. 1a, vertical slice, fig. $1 \mathrm{~b}$, coronal slice). The surrounding gastric wall was edematous and thickened. There was no evidence of free air or perforation of the gastric wall. Three-dimensional reconstruction of the CT images (fig. 1c) revealed an ulcerous lesion at the upper posterior wall of the stomach. Since the tongue cancer occupied the oral space, it was difficult to perform endoscopy. However, the CT findings were highly suggestive of a gastric ulcer. We performed an endoscopic examination using an ultrathin endoscope. Two routes of endoscopy were considered: transnasal ultrathin endoscopy through a crevice of the tongue cancer, or ultrathin endoscopy through a percutaneous gastrostomy route. First, we attempted transnasal ultrathin endoscopy through a crevice in the tongue cancer. Fortunately, transnasal ultrathin endoscopy passed the crevice of the cancer. Transnasal ultrathin endoscopy (fig. 1d) revealed a gastric ulcer in the posterior wall of the stomach, confirming the CT findings. A biopsy specimen of ulcer lesion revealed no findings of malignancy.

\section{Discussion}

With the advances in CT imaging, CT can result in precise imaging, even of the gastrointestinal tract [1-3]. CT virtual gastroscopy is a new noninvasive technique capable of creating high-quality detailed three-dimensional images of subtle mucosal changes in the stomach [1-3]. In this case, we did not perform any specific preparation for CT virtual gastroscopy such as oral administration of gas-producing crystals. As a result, the three-dimensional CT imaging findings were unclear. However, CT could reveal the ulcerous lesion. Chen et al. [1] reported that the image quality of CT virtual gastroscopy is diagnostically comparable to that provided by optical endoscopy. The diagnostic quality of endoscopy is superior to CT because of precise mucosal observations or biopsy procedure. In the present case, CT was useful in the diagnosis of a gastric ulcer because endoscopy was deemed too difficult to perform. CT may therefore be helpful for the diagnosis of gastric lesions when usual endoscopy is difficult to perform, as observed in the present patient.

\section{Disclosure Statement}

The authors have no conflict of interest. 


\begin{tabular}{r|l|l|l}
$\begin{array}{r}\text { Case Reports in } \\
\text { Gastruenterology }\end{array}$ & $\begin{array}{l}\text { Case Rep Gastroenterol 2011;5:136-138 } \\
\text { DOI: 10.1159/000326939 }\end{array}$ & $\begin{array}{l}\text { Published online: } \\
\text { April 6, 2011 }\end{array}$ & $\begin{array}{l}\text { O 2011 S. Karger AG, Basel } \\
\text { ISSN 1662-0631 } \\
\text { www.karger.com/crg }\end{array}$ \\
\hline
\end{tabular}
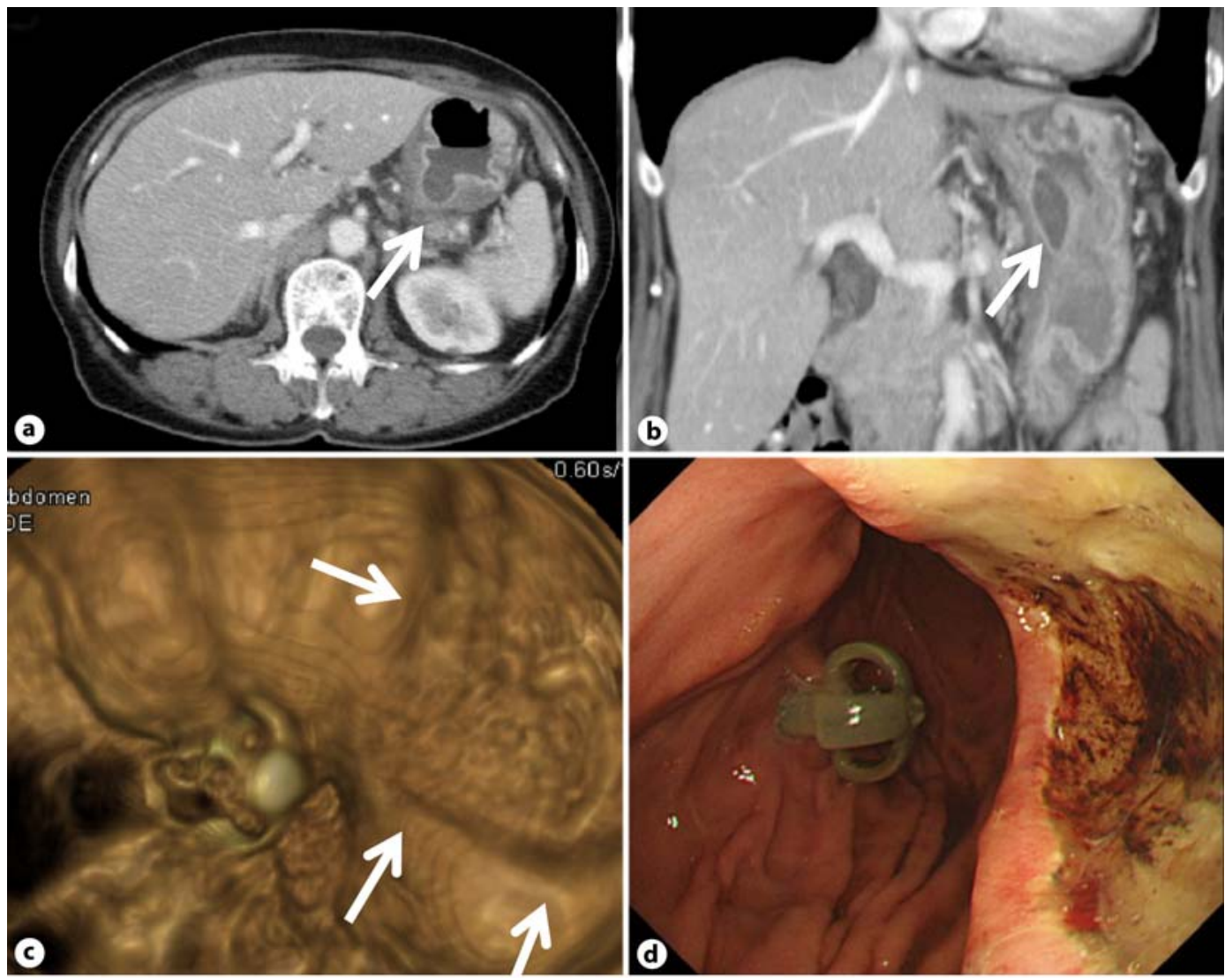

Fig. 1. a CT. Vertical slice. The arrow indicates the mucosal defect in the upper posterior wall of the stomach. b Coronal slice. c Three-dimensional CT imaging of the ulcerous lesion. $\mathbf{d}$ Endoscopic findings. Transnasal ultrathin endoscopy revealed a gastric ulcer in the posterior wall of the stomach, confirming the CT findings. The top of the percutaneous gastrostomy tube was observed in the anterior wall.

\section{References}

$\checkmark 1$ Chen CY, Kuo YT, Lee CH, Hsieh TJ, Jan CM, Jaw TS, Huang WT, Yu FJ: Differentiation between malignant and benign gastric ulcers: CT virtual gastroscopy versus optical gastroendoscopy. Radiology 2009;252:410-417.

2 Inamoto K, Kouzai K, Ueeda T, Marukawa T: CT virtual endoscopy of the stomach: comparison study with gastric fiberscopy. Abdom Imaging 2005;30:473-479.

-3 Bhandari S, Shim CS, Kim JH, Jung IS, Cho JY, Lee JS, Lee MS, Kim BS: Usefulness of three-dimensional, multidetector row CT (virtual gastroscopy and multiplanar reconstruction) in the evaluation of gastric cancer: a comparison with conventional endoscopy, EUS, and histopathology. Gastrointest Endosc 2004;59:619-626. 